\title{
AN APPROACH TO THE MODERN HISTORY OF AFGHANISTAN
}

\author{
TAKeshi Katsufuji*
}

\section{Geographical Features}

To begin with, Afghanistan is defined as a mountainous and landlocked country from the topographical point of view. The Hindukush Mountains form its axis running NE-SW, and present a major barrier to communications between the northern and southern regions of the country. Let the author give an example.

When Arnold J. Toynbee crossed the western part of the range at the Sabzak Pass, after starting from Herat by jeeps in May 1960, his party came to a standstill at several spots. (1) At that season of the year, rivers were full of water due to heavy rainfalls, with no bridges to cross them, and the road was covered with thick snow at the top of the pass.

Every local inhabitant witnesses how dangerous the pass is for cars to proceed, because there are towering peaks and precipitous canyons along the road, and the weather sometimes becomes unfavorable. A phrase from a poem entitled "Shu dao nan" (Perilous Road into Shu, or Si-chuan) written by a Chinese poet Li Po may be applied here: "One soldier can block ten thousand men at this narrow gorge." For this reason, Afghanistan provided a barrier to defend British India from the Russians.

Mountains in Afghanistan are mostly naked and barren; accordingly, wherever the slope is not too steep, they are traversable for human and animal feet, while often preventing wheels from rolling even on the main roads.

Toynbee discusses the means of transportation in Afghanistan under the title "Feet versus Wheels": "Most of the choices of alternative routes that are open to a mule or a man are ruled out for a land-rover."'(2) As the historic routes by feet are completely different from those by wheels, a student of the history of this country should consult caravan-conductors, if he wants to get an

* Professor, Osaka University of Foreign Studies. 
idea of ancient passages there.

Through these gigantic walls of a mountain range, Soviet engineers and Afghan workers opened a tunnel in 1964 . It is $2.7 \mathrm{~km}$. long, and 3,363mt. above the sea level below the Salang Pass, which is located $80 \mathrm{~km}$. north of Kabul. This new highway has brought the Afghan capital closer to Russia in time. The Salang Tunnel is, however, maintained by a large amount of human labor at any season of the year, and is nowadays nervously guarded against guerrillas' attack at any time of the day.

Afghanistan is, as mentioned above, an inland country. Communications with the outside world are carried out mainly by way of Pakistan, against which Afghanistan has had serious ethnopolitical problems which will be discussed below in detail.

When the diplomatic relations between the two countries became worse, transit facilities were refused by Pakistani authorities, while smugglings always play an important role in the Afghan foreign trade. The best trading and aiding partner of this isolated country is, needless to say, a superstate just north of the Amu Darya, across which a combined road and rail bridge was completed in 1982. It is a link to unite the two countries more tightly, and is far away from rebels' bases. To quote a Japanese proverb, "If you stand under a tree, choose a big one."

Another geographical feature of Afghanistan is that its economy is supported primarily by stockraising and farming. Production of food like wheat, sheep and milk, is sufficient to feed the population in their traditional way of life. No petrol has been commercially exploited. The West sees Pakistan as a better partner in all respects, including easier accessibility to it from the sea. Having lost the role of crossroads of civilization after the European overseas expansions, this landlocked region has been left behind the world development, although the peoples there proudly adhere to their traditions.

Next, the author discusses the ethnological situations in Afghanistan. Its population contains a variety of elements, and most of the main ethnic groups in it have co-ethnic partners in neighboring countries. For example, Pashtuns $^{(3)}$ of the equal size to those living in Afghanistan inhabit the North-West Frontier Province of Pakistan. Each of Tajik, Uzbek and Turkoman tribes in the northern part of Afghanistan has built a respective republic for itself in Soviet Central Asia. The Hazaras are common with most of the Iranians in the faith of Shi'a sect of Islam. 
The rulers of Afghanistan had been the Durrani Pashtuns from the start as a state in 1747. The Sadozais and the Muhammadzais were privileged clans among them. One of the main hostile groups against them is the Ghilzais, from which Taraki and Amin, leaders of the 1978 coup, arose. Ghilzais stood at the summit of the state for a brief period, and both of the two died unexpected death.

The abdication of King Zahir Shah in 1973 and the murder of President Prince Da'ud in 78 brought the Muhammadzais into a total decline in terms of political privileges. In common with other Middle Eastern countries, Afghanistan has no ruling class or ruling institutions, therefore there is no substitute for the Muhammadzais. The 78 regime which was inspired by the aggressive northern neighbor has produced the vacuum of authority inside the country. Afghanistan's future is thus largely dependent on the personality of leaders, whether on the side of regime, or of resistance.

Thirdly, an ethno-political problem, called "Pashtunistan" dispute, should be taken into consideration. The Afghan government denounced the validity of the boundary, named the Durand Line, which was demarcated in 1893 after the negotiation with the British India. The border has been internationally recognized, even after the British left India and the successor state Pakistan came into being. From the Afghan standpoint, the Pashtun areas beyond the border as far as the Indus River is "Pashtunistan", not a portion of Pakistani dominion. Kabul government supported the rebels against their rulers. What is the goal of their resistance? "Independent Pashtun State"? Such a small unit will not survive by itself. Which do they prefer as their homeland, Afghanistan or Pakistan? It is up to themselves. In any case, Pakistani sovereignty over them has a history for a century, and has not been brought up for international discussions.

Da'ud Administration strongly condemned the opponent one. Around 1960, when the author was in Kabul studying Pashto language, Radio Kabul had a programme of "Pashtunistan Hour" every evening, where an abusive phrase "Pakistani Imperialistic Government" was repeatedly announced. Da'ud's uncompromising policy resulted in the severance of diplomatic relations with Pakistan in 1961. Official transportations through Pakistan stopped, which meant economic hardship to this inland country. Soviet Premier Khrushchev backed Da'ud in this issue against Pakistan which was a puppet manipulated by America in his eyes. In May 1960, he got mad to hear that the shot down Vol. XXII 1986 
U2 spy-plane left the US air-base near Peshawar, and he even delcared the counterattack.

\section{Dynastic Successions}

Bernard Lewis describes the nomad society in Arabia at the advent of Prophet Muhammad: "The political organisation of the tribe was rudimentary. Its head was the Sayyid or Sheikh, an elected leader who was rarely more than a first among equals. ... The Sheikh was elected by the elders of the tribe, usually from among the members of a single family, ... He was advised by a council of elders called the Majlis, consisting of the heads of the families and representatives of clans within the tribe."(4)

This is an excellent theory, because it can be applied to nomad societies in general. The author here picks up as examples those of the Mongols under Genghis Khan in the 12th and 13th centuries, and of the Pashtuns since the 18th century.

The following diagram of the terminology of political organization will show the similarity among those three societies.

\begin{tabular}{|c|c|c|c|}
\hline Nation & Arabs & Mongols & Pashtuns \\
\hline Title of Head & sayyid, sheikh & khan & shah, amir \\
\hline Family of Head & Banu Hashim & Borjigin & Sadozai, later Muhammadzai \\
\hline Name of Council of Elders & majlis & kuriltai & jirga \\
\hline
\end{tabular}

Let the author make a brief reference to Chinese dynasties since A. D. 1000. We find in the geneologies two types of royal succession system: vertical and horizontal. Vertical one is of pure Chinese, that is, father to son, or to lower generation in the case of no son. In horizontal case, the crown goes brother to brother. It is often found in nomad families, where the most efficient man should be the leader.

Song Dynasty is almost perfect in this system, and Qing Dynasty, although of Manchu origin, was wise enough to adopt the Chinese way of succession. Yuan Dynasty founded by the Mongols was, on the contrary, short-lived, its life being less than one hundred years which is considered a man's life in Chinese literary expression.

The Mongol succession was not hereditary, but elective according to the nomad custom. The death of a khan led to struggle for sovereignty among the 
royal families, which broke the unity of the empire and brought the rapid decline of a nation which had once been so well-known for its outstanding valor and military maneuvers.

Now we come to Afghanistan in question, where Ahmad Shah of Sadozai was elected Head of Afghan Confederacy in 1747. In 1826, Dost Muhammad from other family took over supremacy, whose descendants are called Muhammadzais after his name. Under his rule, Afghan provinces, such as Peshawar, Kashmir, and Kabul, were entrusted to his brothers as governors. He was "a first among equals." As for his territory, he ceded Peshawar and Kashmir to the Sikhs, then to the British, but added Herat, the keypoint in the west, to his possession.

Abd al-Rahman, Dost Muhammad's grandson, is the most important king in the history of Afghanistan. Bringing Turkistan south of the Amu Darya under his control, he built up Afghanistan as we see it on the map.

At first, his government was "rudimentary". According to Louis Dupree, "When Abd al-Rahman came to the throne in Kabul, ten clerks under the guidance of one official handled all the central government administration,"(5) which he later developed in a little modernized form.

$\mathrm{He}$ agreed on the eastern boundary as the result of the negotiation with Mortimer Durand, the Indian government's foreign secretary. This Durand Line is an artificial border, because it cuts the turbulent Afghan inhabitants into two in order to weaken their resistance against the British rule. From the Afghan viewpoint, the border has ever since remained the most serious international problem, difficult or even eternally impossible to solve.

In the internal unification, Abd al-Rahman was called the "Iron Amir", and indeed the only absolute monarch of his country. Dupree writes: "Abd al-Rahman died in 1901. A rare event in Afghan history occurred, and Habib Allah, Abd al-Rahman's eldest son and close confidant, succeeded to the throne without the usual fratricidal fighting, ... He had wisely kept his sons in Kabul and had not made them provincial governors." (6)

Hasan Kakar writes about the same theme: "The amir was careful to see that his sons did not become a menace to him. For this reason, the amir did not appoint any of his sons to be governors of provinces, where the temptation for a prince to defy the central government had always been great in the past."(?)

After the Iron Amir, three successive kings: Habib Allah, Aman Allah and Nadir Shah, met unfortunate end. 


\begin{tabular}{|c|r|l|}
\hline King & Reign & \multicolumn{1}{|c|}{ Cause of End } \\
\hline Habib Allah & $1901-19$ & Assassinated at a winter resort \\
Aman Allah & $19-29$ & Exiled to Rome \\
Nadir Shah & $29-39$ & Assassinated at the capital \\
\hline
\end{tabular}

In 1939, Nadir Shah's eldest son assumed the crown as Zahir Shah at the age of nineteen. He had influential uncles; Muhammad Hashim, Shah Wali and Shah Mahmud, and competent cousins; Muhammad Da'ud and Muhammad Na'im. Zahir Shah was again a first among equals. The uncles guided the young king, then in 1953, Da'ud came to the status as prime minister, with his younger brother $\mathrm{Na}$ 'im as a deputy prime minister. Brother collectivity including the king worked well for a decade, when the critical problem of the Durand Line on which Da'ud stood too firm put him into difficult position. He stepped down in 1963.

This is an example of turburi, rivalry among cousins, one of Pashtun customs. ${ }^{(8)}$ After prime ministers not of royal birth, whose position were unstable and terms short, Prince Da'ud reappeared by a bloodless coup, now as President of the Republic of Afghanistan in 1973. It was, however, still in the hands of a Muhammadzai ruler.

After discussing the fall of the Afghan monarchy, Kakar concludes: "The principle of hereditary succession to the throne had not taken root in Afghanistan. The personality of the rulers was, in effect, more important than the constitutions aimed at institutionalizing the monarchy."( $(9)$ Constitutions have been promulgated several times since 1923, but on each occasion it was only a political declaration at the beginning of a new regime. When the regime collapsed, its constitution was also wiped out. There is no continuity or security in the political organization of Afghanistan.

\section{Political Leaders' Personality}

Now that we have seen Afghanistan's destiny depends on the personality of the rulers, we will single out the ruling élite in the past and the present, and arrange their brief personal history so far as it is available to me. The future leaders, however, will in all probability rise from obscurity outside this list. God knows who wins the sway. 


\section{Last Five Premiers under the Monarchy}

1. former post, 2. term of office, 3. later status.

I Muhammad Yusuf, Ph. D. in physics from the Univ. of Göttingen 1. Minister of Mines and Industry, 2. 1963-65, 3. alive after 78 coup.

II Muhammad Hashim Maiwandwal 1. Minister of Press and Information, 2. 65-67, 3. died in prison in 73 coup.

III Nur Ahmad Etemadi 1. Minister of Foreign Affairs, 2. 67-71, 3. alive after 78 coup.

IV Abdul Zahir, Ph. D. in medicine from Columbia Univ. 1. Speaker of the Lower House (65-69), Ambassador to Italy, 2. June 71-Dec. 72, 3. unknown.

V Muhammad Musa Shafiq, M. A. in law from Azhar (Cairo) and Columbia Univs. 1. Director of Law Department of the Ministry of Justice, Minister of Foreign Affairs, 2. Dec. 72-July 73, 3. executed in 78 coup.

\section{Seven Leaders after $78 \operatorname{Coup}^{(10)}$}

1. year(s) of birth (and death), 2. place of birth, 3. ethnicity, 4. father's status, 5. academic career, 6. occupations before political commitment, 7. political sect; Khalqi or Parchami of PDPA,(11) 8. remarks.

I Nur Muhammad Taraki 1. 1917-79, 2. Muqur, SW of Ghazni, 3. Ghilzai Pashtun, 4. poor and seminomadic livestock dealer, and small-time smuggler, 5. elementary school in Muqur, high school in Kandahar, 6. trading company in Bombay, Ministry of Economics, Press Department, American Embassy in Kabul, 7. Khalqi, publisher of Khalq newspaper, 8. man of letters in favor of socialistic realism, publishing some of his novels from the Pashto Academy.

II Hafizullah Amin 1. 29-79, 2. Paghman, summer quarters $20 \mathrm{~km}$. west of Kabul, 3. Ghilzai Pashtun, 4. minor government clerk, 5. primary school in Paghman, high school in Kabul, Kabul Univ., Science Faculty, Mathematics and Physics Dept., M. A. in education from Columbia Univ., 6. teacher at the Teachers College in Kabul, principal of the Ibn-sina High School (teacher-training), 7. Khalqi.

III Babrak Karmal 1. 29- 2. Kamari near Kabul, 3. probably Tajik, 4. Lt. Gen. Muhammad Husain, governor general of Paktiya province under the king, 5. Najat High School (German school) in Kabul, Kabul Univ., 
Faculty of Law and Political Science, 6. Ministries of Education and Planning, 7. Parchami, 8. gifted speaker, without talent as a writer.

IV Sultan Ali Kishtmand 1. 36- 2. near Kabul, 3. Hazara, Shi'a Muslim, 4. petty trader, 5. Kabul Univ., Faculty of Economics, 6. Ministry of Mines and Industry, 7. Parchami, 8. prime minister (June 81-Dec. 86).

V Muhammad Aslam Watanjar 1. 46- 2. Paktiya province, 3. probably Pashtun, 4. unknown, 5. military school, then in the USSR, 6. tankofficer with the grade of Jagran (Major) in 78 coup, 7. neutral, "primary allegiance to the USSR," 8. "The Soviets may see him as a possible future leader of the country."

VI Najibullah 1. 47- 2. Paktiya province, 3. Ahmadzai, Ghilzai Pashtun, 4. diplomat, 5. Habibia High School (English-language) in Kabul, Kabul Univ., Faculty of Medicine, 6. none, 7. Parchami, 8. head of KHAD(12) (80-85), secretary general of PDPA since May 86.

VII Ahmad Shah Mas'ud 1. circa 54- 2. Panjsher, Kapisa province, 3. Tajik, 4. army officer, 5. Lycée Istiqlal (French-patterned) in Kabul, Kabul Univ., Faculty of Engineering, 6. none, 7. Jami'at (or Jama'at)-i Islami (Islamic Society), with mainly Tajik in membership, 8. charismatic rebel.

Though the author is not trained in psychology, he tries to classify the above listed leaders into three categories of character according to their appearance in photographs.

The first group may be called najib (gentle) type, to which Taraki and Kishtmand belong. King Zahir Shah is of the same type.

The second one is zarang (smart) type, including Amin and Watanjar.

The third is gardan-kuluft (thick-necked, sturdy) character. Karmal and Najibullah, and Prince Da'ud are in this category.

Mas'ud is a slender man with a Kashmir hat always on. He looks pathetic. He is unique among resistance leaders, because he lives in his home province, with occasional absences. His territory is the Panjsher Valley, which is astride the regime's two strategic points; the Salang tunnel and the Begram air-base. He is coping with the Soviet ground and air forces at the head of poorly equipped and supplied mujahidin.(13)

The author has a hypothesis about Mas'ud. He might have made a secret agreement with the Soviet commander in Afghanistan, in disregard of Moscow and Kabul. In advance of launching an offensive on the Panjsher, the Russians may inform Mas'ud of it in one way or another. At this benevolent piece 44

ORIENT 
of information, he leaves his autonomy accompanied by thousands of soldiers and tens of thousands of civilians. Soviet gun-fires and bombings destroy rebels' evacuated homes. When a round of apparently ferocious assault is brought to an end, Mas'ud and his partisans return to their homeland. In this way, both parties continue fightings intermittently at the sacrifice of mud-brick buildings, taking the least human lives. It is a holy war both socialistic and Islamic.

\section{Notes}

(1) Arnold J. Toynbee, Between Oxus and Jumna, Oxford Univ. Press, 1961, pp. 76-80. Toynbee (1889-1975) has world-wide fame for his works, including A Study of History. He is sometimes misunderstood as a macroscopic historian. However, anyone who appreciates the travelogue of Afghanistan quoted above, will see how micro- his approach is. His vast knowledge, wide experiences and keen observations have made him a specialist on Afghanistan as well. When he was travelling in that country, I was also there, attending Professor Shinobu Iwamura. Toynbee says: "At this very moment (May 13, 14, at Surkh Kotal) my Japanese friend, Professor Iwamura of the University of Kyoto, was on his way to Badakhshan in order to study the nomads' life up there in their summer pastures round Lake Shiwa." (p. 106)

(2) Toynbee, ibid., pp. 119-120.

(3) "Pashtun" is their own designation, while they are refered to by others as "Afghan" in Afghanistan and "Pathan" in Pakistan.

(4) Bernard Lewis, The Arabs in History, Hutchinson Univ. Library, (1st ed. 1950), 1968, p. 29. His Istanbul, Univ. of Oklahoma Press, 1963, is recommended in terms of "the ruling élite" in the Middle East. I was fortunate to attend his lecture at Kyoto University in 1975. He had just moved from London to Princeton.

(5) Louis Dupree, Afghanistan, Princeton Univ. Press, 1973, p. 420. As an American anthropologist, Dupree has worked in and on Afghanistan since 1949. This 750 page volume provides encyclopaedic information of Afghanistan. I saw him once at a party in Kabul around 1960, where he danced Pashtun folk dance atan by jerking his head with GI cut hair, instead of Pashtun long hair.

(6) Dupree, ibid., pp. 428-9.

(7) Hasan Kawun Kakar, Government and Society in Afghanistan, The Reign of Amir 'Abd alRahman Khan, Univ. of Texas Press, 1979, p. 16. Kakar is my teacher of Pashto at Kabul Univer. sity, 1959-61. There has been no contact between us since then. He is highly estimated by Thomas E. Gouttierre as "the most conscientious and thorough Afghan historian," The Middle East Journal, autumn 1980, p. 490.

(8) Kakar, "The Fall of the Afghan Monarchy in 1973", International Journal of Middle East Studies, May 1978, p. 207.

(9) Kakar, ibid., p. 214.

(10) Main source; Anthony Arnold, Afghanistan's Two-Party Communism, Hoover Institution Press, 1983.

(11) PDPA is the People's Democratic Party of Afghanistan, or Jami'at-i Dimokratik-i Khalq-i Afghanistan in Persian. It was founded in 1965, then two newspapers were published by some of the members, which represent two sects of that party; Khalq (People), Pashto/Persian weekly, published Apr.-May 1966, with only six issues, and Parcham (Flag), Pashto/Persian weekly, Mar. 68-July 69.

(12) KHAD stands for Khidmat-i Ittila'at-i Daulati (The Government Intelligence Service). 
It is the secret police, or Afghan version of the Soviet KGB. In the Arabic script, initial short vowel of a word, like "i" here, is indicated by the letter "A" (alif).

(13) Mujahid is an Arabo-Persian word which means 'soldier of the holy war.' Its plural form mujahidin is now popular in the Middle Eastern journals. 